\title{
Fasciola hepatica IN BOVINES IN BRAZIL: DATA AVAILABILITY AND SPATIAL DISTRIBUTION
}

\author{
Sita C. BENNEMA(1), Ronaldo Guilherme Carvalho SCHOLTE(1), Marcelo Beltrão MOLENTO(2), Camilla MEDEIROS(1) \& Omar dos Santos CARVALHO(1)
}

\begin{abstract}
SUMMARY
Fasciolosis is a disease of importance for both veterinary and public health. For the first time, georeferenced prevalence data of Fasciola hepatica in bovines were collected and mapped for the Brazilian territory and data availability was discussed. Bovine fasciolosis in Brazil is monitored on a Federal, State and Municipal level, and to improve monitoring it is essential to combine the data collected on these three levels into one dataset. Data were collected for 1032 municipalities where livers were condemned by the Federal Inspection Service (MAPA/SIF) because of the presence of $F$. hepatica. The information was distributed over 11 states: Espírito Santo, Goiás, Minas Gerais, Mato Grosso do Sul, Mato Grosso, Pará, Paraná, Rio de Janeiro, Rio Grande do Sul, Santa Catarina and São Paulo. The highest prevalence of fasciolosis was observed in the southern states, with disease clusters along the coast of Paraná and Santa Catarina and in Rio Grande do Sul. Also, temporal variation of the prevalence was observed. The observed prevalence and the kriged prevalence maps presented in this paper can assist both animal and human health workers in estimating the risk of infection in their state or municipality.
\end{abstract}

KEYWORDS: Fasciola hepatica; Spatial distribution; Cattle; Zoonosis; Brazil.

\section{INTRODUCTION}

Fasciola hepatica is a trematode that parasitizes the liver of the final host and can infect several species including ruminants, equines, pigs, several wild mammals and humans. To complete its lifecycle, $F$. hepatica needs a snail intermediate host of the Lymnaeidae, in Brazil Pseudosuccinea columella, Galba viatrix, Galba cubensis, Galba truncatula and Lymnaea rupestris. Except for L. rupestris, the other species have proved to be susceptible to infection by $F$. hepatica.

Fasciolosis is responsible for a decrease in animal welfare and significant economic losses in the cattle and sheep rearing sector ${ }^{54}$. It has been recognized as an emerging zoonosis and is included in the list of neglected tropical diseases. The disease mostly affects inhabitants of rural areas endemic for animal fasciolosis, who are at risk of ingesting metacercariae through consumption of contaminated water or freshwater plants $^{16,34,49,56}$.

The spatial distribution of $F$. hepatica depends strongly on the presence of the intermediate hosts, and thus on climatic and environmental factors providing a suitable habitat for these snails. In Brazil, the area most known for the presence of $F$. hepatica in cattle is the South region ${ }^{8,17,23,50}$, but bovine fasciolosis has also been noted in the states of Rio de Janeiro, São Paulo, Espírito Santo, Minas Gerais and Goiás ${ }^{6,9,11,20,22,25,29,30,36,48,51,52,55}$. So far, around 50 cases of human fasciolosis have been described in Brazil, most of them in Paraná $a^{3,4,14,27,37,40}$. Due to poor awareness about human fasciolosis, this number is likely to be an underestimation.

Knowledge about the spatial distribution of fasciolosis in cattle in Brazil can contribute to the identification of risk areas for infection of both animals and humans. Focusing parasite control programs on these areas will lead to an increase of the cost-effectiveness of control. Previous studies on the spatial distribution of $F$. hepatica in cattle have concentrated on the southern states ${ }^{15,17,50}$. Therefore, in this paper we discuss the data availability for bovine fasciolosis in Brazil and provide the first description of the spatial distribution of bovine fasciolosis in the entire Brazilian territory.

\section{MATERIAL AND METHODS}

Study area: The Brazilian territory comprises $8,514,215.3 \mathrm{~km}^{2}$ and is divided in five regions, 27 states and 5567 municipalities ${ }^{26}$. According to the Köppen climate classification system, the climate varies from equatorial and tropical in the north to semiarid in the northeast, highland tropical at the highlands of Brasília, Belo Horizonte and São Paulo and subtropical or even temperate in the South. In 2006, the total cattle herd in Brazil was 205.9 million heads ${ }^{24}$. Cattle production takes place in the entire Brazilian territory, but is concentrated in the central west region, predominantly in the states of Mato Grosso, Mato Grosso do Sul and Goiás ${ }^{24}$.

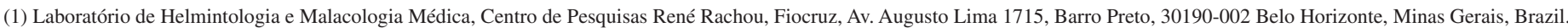
(2) Laboratório de Doenças Parasitárias, Setor de Ciências Agrárias, Universidade Federal do Paraná, Rua dos Funcionários 1540, Cabral, 80035-050 Curitiba, Paraná, Brazil. 
BENNEMA, S.C.; SCHOLTE, R.G.C.; MOLENTO, M.B.; MEDEIROS, C. \& CARVALHO, O.S. - Fasciola hepatica in bovines in Brazil: data availability and spatial distribution. Rev. Inst. Med. Trop. Sao Paulo, 56(1): 35-41, 2014.

Data collection: For this study, liver inspection data were used of cattle slaughtered in establishments registered with the Federal Inspection Service (SIF) of the Ministry of Agriculture, Livestock and Supply (Ministério da Agricultura, Pecuária e Abastecimento, MAPA). These data were collected from the period of 2002 to 2011. The data were registered on the municipality of origin.

The databank of SIF only includes the municipalities where livers have been condemned, and no 'absence data' was available. Absence of data for municipalities can therefore either mean the absence of $F$. hepatica, or the absence of inspection data.

In order to distinguish between the absence of $F$. hepatica and the absence of data, figures of the Brazilian Institute of Geography and Statistics (IBGE) on the number of slaughtered cattle and type of inspection per state were used to construct maps displaying the percentage of cattle slaughtered under federal, state and municipal inspection ${ }^{25}$. This map was made using the IBGE figures for 2010. In Figure 1, establishments registered with the SIF were marked at the centroids of the municipalities.

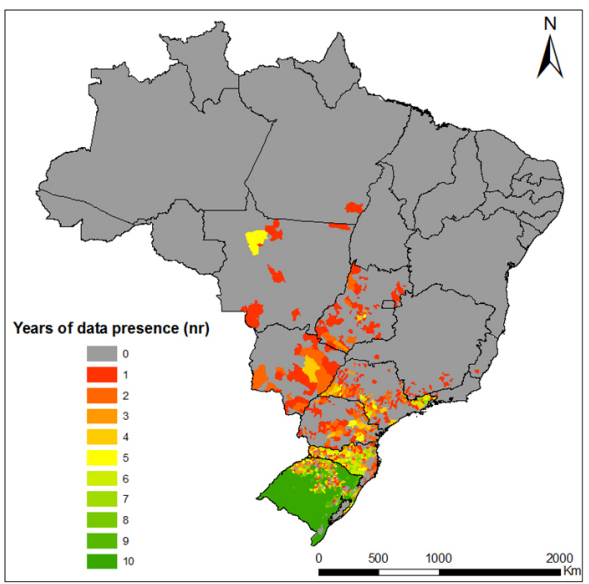

Fig. 1 - Data availability per municipality on bovine fasciolosis in Brazil in the period of 2002-2011. The colors show the number of years for which prevalence data was available. Geographic Coordinate System, Horizontal Datum: WGS84.

Descriptive statistics and exploratory spatial analysis: Descriptive statistics were calculated using Statistica 6.0 (Statsoft; Tulsa, OK, USA) and $\mathrm{R} 2 \cdot 15.0^{46}$.

The prevalence of $F$. hepatica was mapped using ArcGIS 9.3 (ESRI; Redlands, CA, USA). A single database was constructed containing the prevalence data per municipality for the years 2002 to 2011 . This database was joined with the map of municipalities available from the IBGE.

The geographical distribution of $F$. hepatica was further studied using exploratory spatial statistics in ArcGIS. The spatial distribution of the sample was assessed using Ripley's K. This is a statistic that is used to detect deviations from spatial homogeneity. It describes the number of observations within a certain distance of a typical point in the sample, and the function of the sample is compared to the function of the random Poisson distribution ${ }^{7}$. The data were analyzed for presence of 'disease clusters' calculating the Moran's I. The Moran's I is a global cluster statistic and describes the autocorrelation between the values of a variable in a certain location with and the values of this same variable in neighboring locations ${ }^{5}$. The Moran's $I$ was calculated using inverse distance weighing and the bandwidth was set at $750 \mathrm{~km}$ (the bandwidth at which the highest Z-score was obtained).

The clusters were then mapped using Hot Spot Analysis. The Hot Spot Analysis tool in ArcGIS calculates a local Getis-Ord Gi* for each feature in the sample. This statistic compares the sum of a feature's value and that of its neighbors to the sum of the rest of the features, and areas where this sum this is statistically different (higher or lower), are defined as hot or cold spots. In this analysis a fixed bandwidth of $750 \mathrm{~km}$ was used.

As another way of obtaining insight in the spatial distribution of the prevalence of $F$. hepatica, the prevalence was kriged using the spatial analyst tool in ArcGIS. Centroids of the municipalities were calculated and these point data were used for the kriging.

\section{RESULTS}

Data availability: Data were available for 19,696,469 slaughtered bovines distributed over 1032 municipalities (18.5\% of total) of 11 states. Figure 1 shows the number of years the data were available per municipality. It can be observed that the municipalities where $F$. hepatica was detected are concentrated in the southern and central states, whereas in the north and northeast no infected municipalities were detected. Also, in the South, data were available for a longer period of time.

Using the data of IBGE, maps were made displaying the percentage of cattle slaughtered under federal, state and municipal inspection (Fig. 2). Federal inspection is common in the Southern and central states, whereas in the Northeast municipal inspection is more important. State inspection is common practice in Rio de Janeiro, Santa Catarina and Rio Grande do Sul, and to a lesser extent in the Northeast.

Prevalence: Entire Brazil and per state: The total number of cattle in the database was 19,696,469 and the total number of livers condemned due to $F$. hepatica was $1,244,123$. The total prevalence of $F$. hepatica over the period of 2002 to 2011 in Brazil was therefore $6.32 \%$ (95\% Confidence Interval (CI): 6.31-6.33). In Rio Grande do Sul the highest prevalence ( $14.39 \%$ ) was observed, followed by Santa Catarina (4.50\%). In the other states the observed prevalence ranged between 0 and $3 \%$ (see Table 1).

The temporality of the prevalence is described in Figure 3. The prevalence in RS increased to a maximum of $19.18 \%$ in 2006, and then declined to $12.87 \%$ in 2011 . The state of Paraná also saw a maximum prevalence in 2006, of $9.37 \%$. During the other years the prevalence in Paraná was just above zero. Santa Catarina had a prevalence peak $F$. hepatica in $2010(8.26 \%)$ and a sharp decline in 2011. In the other states prevalence was stable and just above zero.

The prevalence in Brazil ranged between 4-8\%, with a peak of $11.55 \%$ in 2006 due to the increased prevalence in RS and SC.

\section{Prevalence: per municipality}

Descriptive statistics: $F$. hepatica was detected in 1032 municipalities 
A

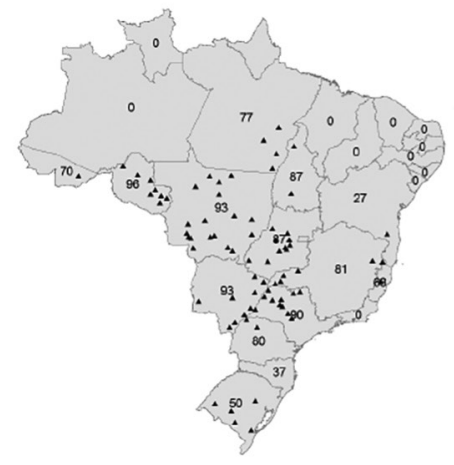

B

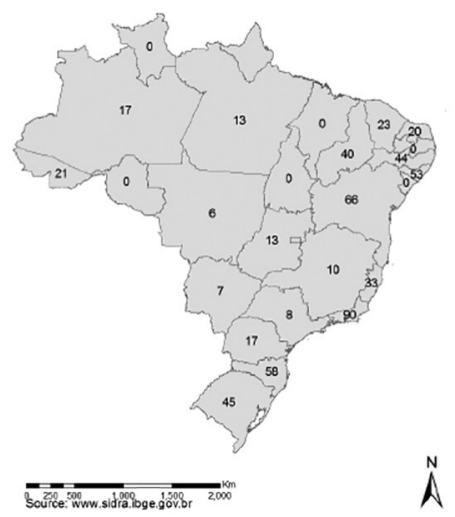

C

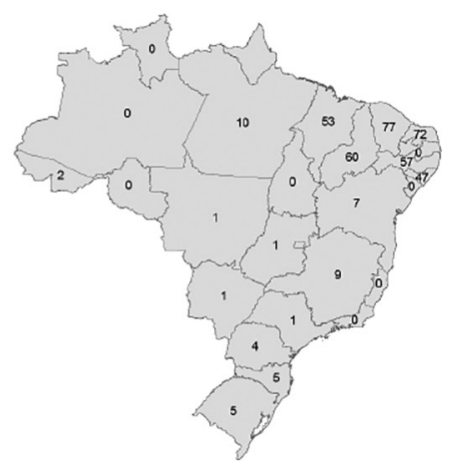

Fig. 2 - The percentage of slaughtered cattle covered by the Federal (A), State (B) and Municipal (C) Meat Inspection Services in Brazil. The black triangles in A represent the municipalities of the abattoirs under Federal Inspection. Geographic Coordinate System, Horizontal Datum: WGS84.

Table 1

Description per state of the total number of municipalities with presence of bovine fasciolosis, the number of animals slaughtered, the number of animals diagnosed with Fasciola hepatica and the prevalence (\%) based on these numbers in Brazil

\begin{tabular}{|c|c|c|c|c|c|c|}
\hline \multirow{2}{*}{ State } & \multirow{2}{*}{ Municipalities (n) } & \multirow{2}{*}{ Animals (n) } & \multirow{2}{*}{ Infected (n) } & \multirow{2}{*}{ Prevalence (\%) } & \multicolumn{2}{|c|}{$95 \% \mathrm{CI}^{*}$} \\
\hline & & & & & Lower & Upper \\
\hline $\mathrm{ES}$ & 1 & 2416 & 52 & 2.15 & 1.61 & 2.81 \\
\hline GO & 50 & 1929432 & 581 & 0.03 & 0.03 & 0.03 \\
\hline MG & 25 & 44269 & 43 & 0.10 & 0.07 & 0.13 \\
\hline MS & 32 & 3931245 & 86 & 0.00 & 0.00 & 0.00 \\
\hline MT & 8 & 1327983 & 40 & 0.00 & 0.00 & 0.00 \\
\hline PA & 1 & 82548 & 1 & 0.00 & 0.00 & 0.00 \\
\hline PR & 108 & 959510 & 734 & 0.08 & 0.07 & 0.08 \\
\hline RJ & 1 & 360 & 4 & 1.11 & 0.30 & 2.82 \\
\hline RS & 409 & 8427727 & 1212966 & 14.39 & 14.37 & 14.42 \\
\hline $\mathrm{SC}$ & 205 & 609416 & 27395 & 4.50 & 4.44 & 4.55 \\
\hline SP & 192 & 2381563 & 2221 & 0.09 & 0.09 & 0.10 \\
\hline
\end{tabular}

* CI, Confidence Interval.

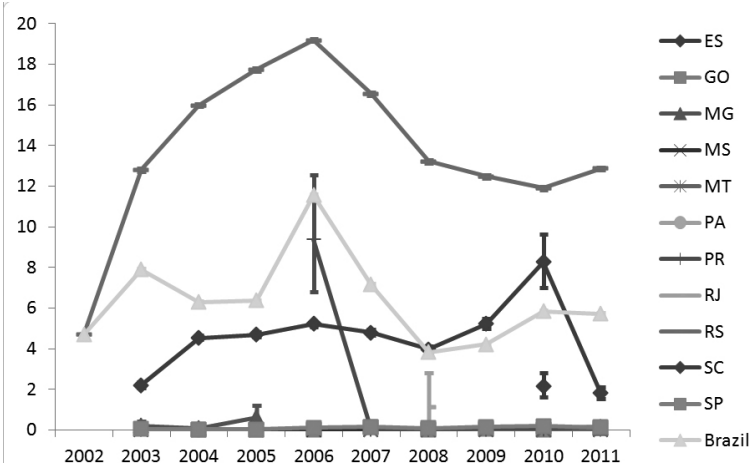

Fig. 3 - The annual prevalence of Fasciola hepatica per state and for the whole of Brazil in the period of 2002 to 2011 (error bars: binomial 95\% Confidence Interval).

distributed over 11 states. The average prevalence per municipality was $7.1 \%$, while the median was $2.69 \%$ : the histogram (Fig. 4) shows that the distribution was skewed to the left, indicating the presence of many municipalities with a low prevalence. The prevalence ranged from 0.00 to $70.90 \%$.

Exploratory spatial statistics: In Figure 5, the spatial distribution of $F$. hepatica in Brazil as estimated from our data was mapped. It can be observed that $F$. hepatica is most densely present in the southern states of RS and SC, followed by SP and PR. Also, a higher prevalence (> 20\%) can be seen in RS and along the coast of SC and PR. Fasciolosis appears to have a more or less even spatial distribution in the states of GO and MS, whilst in MG all infected municipalities present in the database were located in the south of the state. In MT, PA, ES and RJ only a few municipalities with cattle infected with $F$. hepatica were registered.

The Ripley's K values were higher than expected in a randomly distributed dataset, indicating spatial clustering of the sample.

The Moran's $I(0.37, p<0.01)$ confirmed presence of spatial clusters 


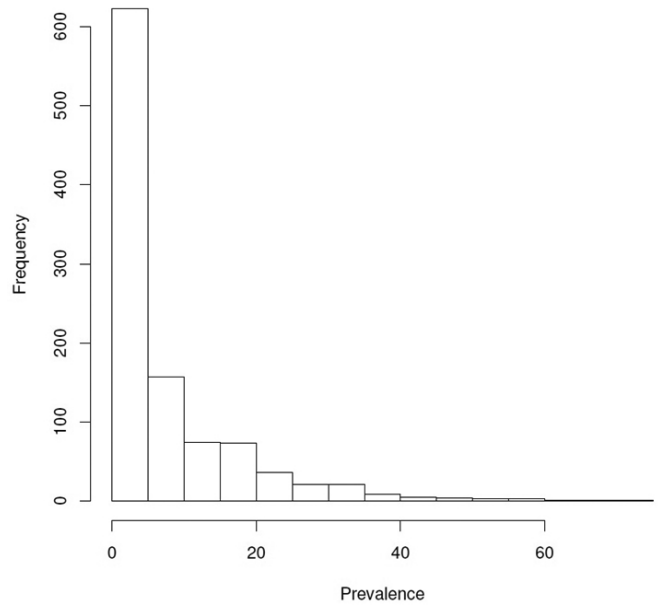

Fig. 4 - Histogram of the prevalence of Fasciola hepatica on municipality level during 2002 to 2011 in Brazil.

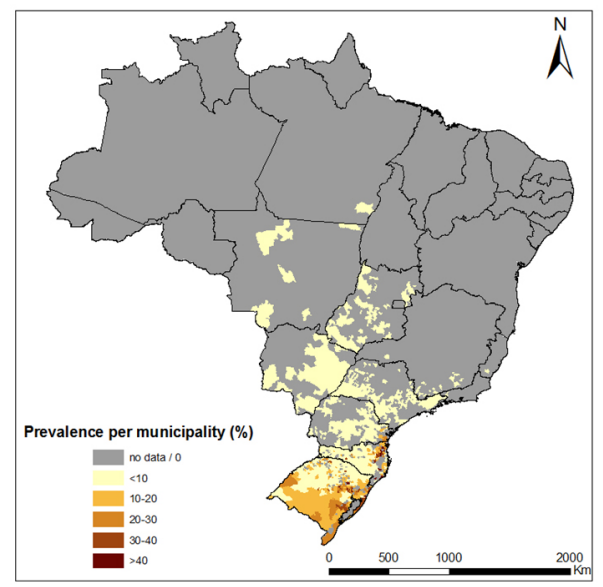

Fig. 5 - The spatial distribution of the prevalence of Fasciola hepatica (\%) in livers of slaughtered cattle per municipality in the period of 2002 to 2011 in Brazil. Geographic Coordinate System, Horizontal Datum: WGS84.

in the prevalence of F. hepatica. Maps of these clusters (figures not shown) showed a significant hot spot in RS and SC and a significant cold spots in PR, SP, MS and GO. Kriging provided a risk map displaying the prevalence of $F$. hepatica (Fig. 6) and confirmed the clustering observed with the hot spot analysis and in Figure 4.

\section{DISCUSSION}

For the first time, georeferenced presence data of $F$. hepatica in bovines were collected and mapped for entire Brazil. F. hepatica is an emerging zoonosis and although transmission to humans is also related to social factors such as dietary habits, mapping the distribution of this trematode in cattle and other final hosts can give indications of the possible risk areas for zoonotic endemicity.

Monitoring of $F$. hepatica in cattle is therefore essential. In Brazil, this happens through inspection at slaughter, but currently, inspection data are not centralized. When mapping the levels of inspection, regional differences were seen: in central Brazil federal inspection is carried out

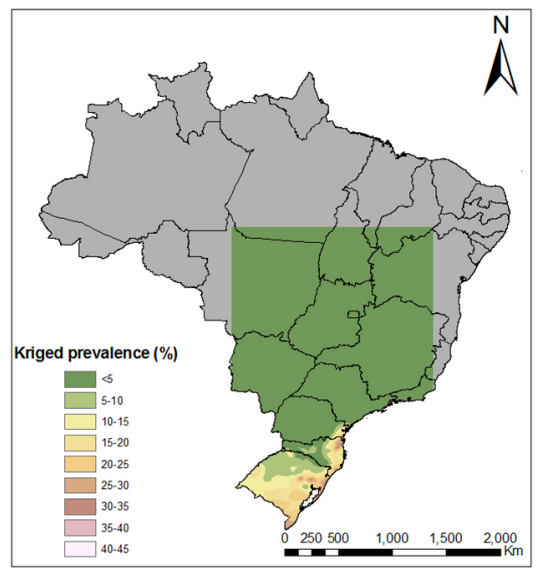

Fig. 6 - The spatial distribution of the prevalence of Fasciola hepatica (\%) in livers of slaughtered cattle per municipality in the period of 2002 to 2011 in Brazil, interpolated using Ordinary Kriging in the spatial analysis tool in ArcGIS. Geographic Coordinate System, Horizontal Datum: WGS84.

regularly, while in the South region, state and federal inspection are combined. The Northeast is the only region where the municipalities have a large share in the inspection, along with the state. In the northern states of Amazonas and Roraima data is very scarce. These large regional differences in type of inspection cause an unequal spatial distribution of the data used in the present study, as only federal inspection data were included. As for the North and Northeast of Brazil no federal inspection data are available, this study fails to provide information about those regions. The lack of data for these areas is due to the scattered data collection and the absence of a unified databank combining the different levels (federal, state and municipal) and a change in this system is essential to improve monitoring of $F$. hepatica and other animal and zoonotic diseases of importance for the veterinary public health; e.g. echinococcosis and cysticercosis.

Notwithstanding possible bias due to nonuniformity in sampling, possible inter-abattoir differences in inspection and uncertainty of the origin of the cattle (cattle migration is not taken into account), the present study provides valuable information about a large area of Brazil, based on many observations and including important livestock regions. Confirming previous literature, the southern states of RS and SC showed the highest prevalence of $F$. hepatica infections ${ }^{17,23}$. In SP, the Vale do Paraíba region was described as an important focus of $F$. hepatica ${ }^{50}$. The presence of fasciolosis in this valley was confirmed by our study.

The presence of $F$. hepatica in RJ and ES is also confirmed by previous literature, although those studies reported a higher number of municipalities infected with $F$. hepatica. For RJ, the only municipality included as positive in our database is Barra Mansa, situated in the RJ part of the Vale do Paraíba. The first record of F. hepatica in Brazil describes the presence of $F$. hepatica in Três Rios, a municipality close to this region $^{31}$, and later studies confirmed presence of $F$. hepatica in various municipalities located there ${ }^{21,43,48,51}$. Fasciolosis was also described in the Norte Fluminense, East and South Region, the Metropolitan Region and the Lagos Region ${ }^{22,29,42,44,51}$. In southern ES all 10 municipalities studied by ALVES et al. (2011) were found positive using coproparasitologic tests and 23 municipalities were predicted to be at risk by a prediction model based on climatic and geographic factors ${ }^{32}$. BERNARDO et 


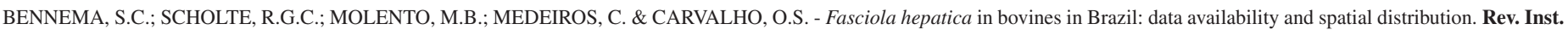
Med. Trop. Sao Paulo, 56(1): 35-41, 2014.

al. (2011) found a prevalence of bovine fasciolosis in Southern ES of higher than $15 \%$ in 2006-2009. The federal inspection data used in our paper included only the municipality of Cachoeiro de Itapemirim, also located in the south.

We found $F$. hepatica in cattle from the southern part of MG (specifically, in the South-Southwest Region and the regions of Zona da Mata, Campo das Vertentes and Triângulo Mineiro/Alto Paranaíba), agreeing with the results of SERRA-FREIRE et al. (1995) and LIMA et al. (2009). However, LIMA et al. (2009) found no presence of $F$. hepatica in Campo das Vertentes and did detect $F$. hepatica in Metalurgica. Itajubá and Careaçú, municipalities in the South of MG known to be endemic areas for bovine fasciolosis ${ }^{13,18,40,51}$, were not included as infected municipalities in the used database, as well as Viçosa, the first municipality of MG to have a case of bovine fasciolosis described ${ }^{12}$. In GO, the presence of fasciolosis had previously been studied by ARAÚJO et al. (2007) who, also using data of MAPA, found a similar distribution as seen in the present study. In MT and MS, the presence of $F$. hepatica in cattle, to the authors' knowledge, has not been described before, although reports of cases of human fasciolosis ${ }^{47}$ and of the intermediate host ${ }^{41}$ indicated the presence of the trematode in the region. For the North and Northeast, not enough data were available since federal inspection is non-existent or scarce in those regions. Although the high temperature in the North and North East might make a high prevalence of F. hepatica unlikely, an outbreak of human fasciolosis has been described in Amazonas and intermediate hosts have been found at several locations in the North and North-East ${ }^{1,40}$.

The maps presented in this paper, combined with knowledge from previous literature and if possible with information from state and municipal inspection, could serve to assist both animal sanitary programs and human health workers in estimating the risk of infection in their state or municipality. According to ROBINSON \& DALTON (2009) the human population at risk of $F$. hepatica infections is, most commonly, people living in rural areas endemic for animal fasciolosis, sharing water sources with the animals and consuming contaminated vegetables. Although high correlation is not always present between a high prevalence of fasciolosis in cattle and in humans ${ }^{33}$, in Brazil an overlap between the disease in both species was seen, as well as an overlap with the presence of Lymnaeidae species ${ }^{10}$. In areas where fasciolosis was traditionally present in cattle, control programs focused on treating livestock and changing management practices on the farms; e.g. fencing wetlands. The latter strategy was suggested to limit the access of cattle into grazing areas where $F$. hepatica positive-snails were present. The treatment with triclabendazole as a preventive strategy is necessary to reduce the infection burden, reducing egg shedding in the suitable environment ${ }^{54}$. Unfortunately these measurements are considered to be inefficient to control the zoonotic spread of the disease in areas where health workers are not properly trained to recognize possible symptoms of fasciolosis in humans and to carry out the adequate diagnostic techniques used to confirm the infection. In the areas where fasciolosis in bovines is endemic, epidemiological studies need to be conducted in humans, to obtain insight into the importance of fasciolosis as a zoonosis in Brazil. In areas endemic for human disease, if present, the population should be informed about the danger and transmission of the disease and educated about the preventive methods (e.g. cooking or freezing before consumption, separation of grazing grounds and cultivation areas). Consumption of unsafe drinking water and freshwater plants possibly contaminated with metacercariae should be strictly controlled ${ }^{16,28,35,49}$. Currently, a lack of monitoring policies exists which hampers the identification of potentially contaminated vegetables and drinking water. For an adequate control and monitoring and a deeper insight in the epidemiology of this increasingly important zoonosis, the development of a laboratory protocol to test for metacercariae is required, so that routine tests can be performed on vegetables and drinking water.

Combining the prevalence data presented in this paper with climatic, geographical and herd-management data, the distribution of $F$. hepatica in Brazil can be modeled and the presence of risk areas can be explained. This could provide a deeper insight in the factors of importance for the distribution of F. hepatica in Brazil and render methods to predict the prevalence in similar areas where no data is available.

Considerable inter annual differences in prevalence were observed in the present study. These might be due to variation in climatic circumstances. On a global scale, there has been an increase in human cases since the 80's, and human and animal fasciolosis is seen as an emerging disease. This emergence might be related to climate and environmental changes $19,35,38,39,45,53$. Studying temporal trends in the prevalence of fasciolosis in cattle will attribute to the understanding of these relations, and can be used to predict eventual geographic shifts and changes in infection rates.

\section{RESUMO}

Fasciola hepatica em bovinos no Brasil: disponibilidade de dados e distribuição espacial

A fasciolose é doença de alta importância para a saúde tanto veterinária quanto humana. Pela primeira vez, dados georreferenciados da prevalência de Fasciola hepatica em bovinos foram coletados e mapeados para o território brasileiro e a disponibilidade desses dados discutida. Fasciolose bovina no Brasil é monitorado em nível Federal, Estadual e Municipal, e para melhorar esse monitoramento é preciso juntar os dados dos três níveis para construir um único banco de dados. As informações foram coletadas de 1032 municípios onde fígados bovinos foram condenados por causa de $F$. hepatica pelo Serviço de Inspeção Federal (MAPA/SIF). Onze estados foram representados: Espírito Santo, Goiás, Minas Gerais, Mato Grosso do Sul, Mato Grosso, Pará, Paraná, Rio de Janeiro, Rio Grande do Sul, Santa Catarina e São Paulo. A prevalência mais alta da fasciolose foi observada nos estados do Sul, com presença de focos da doença ao longo do litoral do Paraná e Santa Catarina e no Rio Grande do Sul. Variação temporal da prevalência também foi observada. Os mapas de prevalência observada e de krigeagem aqui apresentados podem auxiliar a profissionais da área da saúde veterinária e humana a estimar o risco de infecção nos seus estados e/ou municípios.

\section{ACKNOWLEDGEMENTS}

The authors are grateful to Dr. Carlos R. Conti Naumann from the Federal Inspection Service 2354, MAPA (Colombo, PR) for supplying the data from the SIF database. DMV Lew Kan Sprenger is thanked for his help in obtaining the data. The work of R. Scholte was sponsored by the National Council of Technological and Scientific Development (Process 150386/2012-5). 


\section{REFERENCES}

1. Abílio FJP, Watanabe T. Ocorrência de Lymnaea columella (Gastropoda: Lymnaeidae), hospedeiro intermediário de Fasciola hepatica, para o Estado da Paraíba, Brasil. Rev Saúde Pública. 1998;32:184-5.

2. Alves DP, Carneiro MB, Martins IVF, Bernardo CC, Donatele DM, Pereira Júnior OS, et al. Distribution and factors associated with Fasciola hepatica infection in cattle in the south of Espírito Santo State, Brazil. J Venom Anim Toxins incl Trop Dis. $2011 ; 17: 271-6$

3. Amaral AD, Busetti ET. Fasciolose hepática humana no Brasil. Rev Inst Med Trop Sao Paulo. 1979;21:141-5.

4. Andrade Neto JL, Carneiro Filho M, Luz E, Siciliano RF, Oliveira Filho AG, Pisani JC. Human fascioliasis in the metropolitan area of Curitiba, Brazil. Evaluation of the foci of infection and report of nine cases treated with triclabendazole. Braz J Infect Dis. 1999;3:220-5.

5. Anselin L, Syabri I, Kho Y. GeoDa: an introduction to spatial data analysis. Geogr Anal. 2006;38:5-22.

6. Araújo JLB, Linhares GFC, Oliveira APM, Amoril JG, Freitas MR, Costa IC, et al. Infecções autóctones de bovinos por Fasciola hepatica Linnaeus, 1758 (Trematoda, Fasciolidae) no estado de Goiás, Brasil. Rev Patol Trop. 2007;36:96-100.

7. Baddeley A. Analysing spatial point patterns in R. North Ryde NSW Australia: CSIRO Mathematical and Information Sciences; 2008.

8. Beck AAH. Fasciolose bovina. Florianópolis: EMPASC; 1985. (Bol Técn. 1985;33:5-18).

9. Bernardo CC, Carneiro MB, Avelar BR, Donatele DM, Martins IVF, Pereira MJS. Prevalence of liver condemnation due to bovine fasciolosis in Southern Espírito Santo: temporal distribution and economic losses. Rev Bras Parasitol Vet. 2011;20:49-53.

10. Busetti ET. Informações adicionais sobre a fasciolose hepática em Curitiba (Estado do Paraná, Brasil). Rev Inst Med Trop Sao Paulo. 1982;24:104-6.

11. Bruno SF, Mattos Junior DG, Silva EV, Francis M, Brito DB. Fasciola hepatica (Linnaeus 1758) em bovinos do município de Cachoeiras de Macacu. Estado do Rio de Janeiro, Brasil. Parasitol Día. 1995;19:65-8.

12. Carvalho JCM. Contribuição para o conhecimento da fauna helmintológica de Minas Gerais. Ceres (Viçosa). 1940;5:411-23

13. Coelho LHL, Lima WS. Population dynamics of Lymnaea columella and its natural infection by Fasciola hepatica in the State of Minas Gerais, Brazil. J Helminthol. $2003 ; 77: 7-10$.

14. Coral RP, Mastalir ET, Mastalir FP. Retirada de Fasciola hepatica da via biliar principal por coledocoscopia. Rev Col Bras Cir. 2007;34:70-1.

15. Cunha FOV, Marques SMT, Mattos MJT. Prevalência de Fasciola hepatica em ovinos no Rio Grande do Sul, Brasil. Parasitol Latinoam. 2007;62:188-91.

16. Dorny P, Praet N, Deckers N, Gabriel S. Emerging food-borne parasites. Vet Parasitol. 2009;163:196-206.

17. Dutra LH, Molento MB, Naumann CRC, Biondo AW, Fortes FS, Savio D, et al. Mapping risk of bovine fasciolosis in the south of Brazil using Geographic Information Systems. Vet Parasitol. 2010;169:76-81

18. Faria RN, Cury MC, Lima WS. Prevalence and dynamics of natural infection with Fasciola hepatica (Linnaeus, 1758) in Brazilian cattles. Rev Méd Vét. 2005;156:85-6.

19. Fox NJ, White PC, McClean CJ, Marion G, Evans A, Hutchings MR. Predicting impacts of climate change on Fasciola hepatica risk. PLoS One. 2011;6:e16126.
20. Fuji TU, Oliveira SM, Fujii T, Palazzo JPC. Prevalência da fasciolose hepática em búfalos (Bubalus bubalis L., 1758) da região do Vale do Ribeira, São Paulo, Brasil. Arq Inst Biol (S Paulo). 1998;65:11-5.

21. Gomes PAC, Nuernberg S, Pimentel Neto M, Oliveira GP, Arroyo JLB, Rezende HEB, et al. Infecção experimental de Lymnaea columella Say, 1817 com Fasciola hepatica Linnaeus, 1758 de ocorrência no Estado do Rio de Janeiro. Arch Univ Fed Rural (Rio de J). 1974;4:35-8.

22. Gomes FF, Oliveira FCR, Pile EA, Lopes CWG. Estabelecimento de foco de fasciolose hepática em propriedade do município de Campos dos Goytacazes no estado do Rio de Janeiro, Brasil. Rev Bras Parasitol Vet. 2002;11:53-6.

23. Honer MR. Aspectos da epidemiologia da fasciolose. In: I Seminário Nacional sobre Parasitoses de Bovinos, Campo Grande. Anais. Brasília: EMBRAPA/CNPGC; 1979. p. 151-65.

24. Instituto Brasileiro de Geografia e Estatística (IBGE). Brasil. Censo Agropecuária 2006. Rio de Janeiro: IBGE; 2009. 267 p.

25. Instituto Brasileiro de Geografia e Estatística (IBGE). Brasil. Banco de Dados Agregados - SIDRA, 2011, table 1092. [cited: July 2012]. Available from: http:// www.sidra.ibge.gov.br/

26. Instituto Brasileiro de Geografia e Estatística (IBGE). Brasil. 2012. Available from: http://www.ibge.gov.br.

27. Igreja RP, Barreto MGM, Soares MS. Fasciolíase: relato de dois casos em área rural do Rio de Janeiro. Rev Soc Bras Med Trop. 2004;37:416-7.

28. Keiser J, Utzinger J. Food-borne trematodiases. Clin Microbiol Rev. 2009;22:466-83

29. Lessa CSS, Scherer PO, Vasconcellos MC, Freire LS, Santos JAA, Freire NMS. Registro de Fasciola hepatica em eqüinos (Equus caballus), caprinos (Capra hircus) e ovinos (Ovis aries) no município de Itaguaí, Rio de Janeiro, Brasil. Rev Bras Ci Vet. 2000;1:63-4

30. Lima WS, Soares LRM, Barçante TA, Guimarães MP, Barçante JMP. Occurrence of Fasciola hepatica (Linnaeus, 1758) infection in Brazilian cattle of Minas Gerais, Brazil. Rev Bras Parasitol Vet. 2009;18:27-30.

31. Lutz A. Sobre a ocorrência de Fasciola hepatica no estado do Rio de Janeiro. Bol Inst Oswaldo Cruz. 1921;1:9-13.

32. Martins IVF, de Avelar BR, Pereira MJS, da Fonseca AH. Application of a geographical information system approach for risk analysis of fascioliasis in southern Espírito Santo State, Brazil. Geospat Health. 2012;6:S87-S93.

33. Mas-Coma S, Esteban JG, Bargues MD. Epidemiology of human fascioliasis: a review and proposed new classification. Bull World Health Organ. 1999;77:340-6.

34. Mas-Coma S, Bargues MD, Valero MA. Fascioliasis and other plant-borne trematode zoonoses. Int J Parasitol. 2005;35:1255-78.

35. Mas-Coma S, Valero MA, Bargues MD. Climate change effects on trematodiases, with emphasis on zoonotic fascioliasis and schistosomiasis. Vet Parasitol. 2009:163:264-80.

36. Mattos MJT, Ueno H, Gonçalves PC, Almeida JEM. Ocorrência estacional e bioecologia de Lymnaea columella Say, 1817 (Mollusca, Lymnaeidae) em habitat natural no Rio Grande do Sul. Rev Bras Med Vet. 1997;19:248-52.

37. Mezzari A, Antunes HBB, Coelho N, Cauduro PF, Brodt TC. Fasciolíase humana no Brasil diagnosticada por colangiografia endoscópica retrógrada. J Bras Patol. 2000;36:93-5

38. Mitchell GB. Update on fascioliasis in cattle and sheep. In Pract. 2002;24:378-85.

39. Mitchell GB, Somerville DK. Effects of climate change on helminth diseases in Scotland. Ayr: SAC Veterinary Centre Auchincruive; 2005. p. 1-11. 
40. Oliveira AA, Nascimento AS, Santos TAM, Carmo GMI, Dimech CPN, Alves RMS, $e$ al. Estudo da prevalência e fatores associados à fasciolose no Município de Canutama, Estado do Amazonas, Brasil. Epidemiol Serv Saúde. 2007;16:251-9.

41. Paraense WL. Lymnaea rupestris sp. n. from Southern Brazil (Pulmonata: Lymnaeidae). Mem Inst Oswaldo Cruz. 1982;77:437-43.

42. Pile E, Lessa CSS, Scherer PO, Albuquerque Dos Santos JA, de Vasconcellos MC Ocurrencia de fasciolosis bovina en Itaguaí, Rio de Janeiro, Brasil. Parasitol Día. 1999;23:3-4.

43. Pile E, Gazeta G, Santos JAA, Coelho B, Serra-Freire NM. Ocorrência de fascioliasis humana no município de Volta Redonda, RJ, Brazil. Rev Saúde Pública. 2000;34:4134.

44. Pile E, Santos JAA, Pastorello T, Vasconcellos, M. Fasciola hepatica em búfalos (Bubalus bubalis) no município de Maricá, Rio de Janeiro, Brasil. Braz J Vet Res Anim Sci. 2001;38:42-3.

45. Pritchard GC, Forbes AB, Williams DJL, Salimi-Bejestami MR, Daniel RG Emergence of fasciolosis in cattle in East Anglia. Vet Rec. 2005;157:578-82.

46. R Development Core Team. R: a language and environment for statistical computing. Vienna: R Foundation for Statistical Computing; 2008.

47. Rey L. Primeiro encontro de ovos de Fasciola hepatica em inquérito helmintológico de populações brasileiras (Campo Grande, Mato Grosso do Sul). Rev Paul Med. 1958;53:60.

48. Rezende HEB, Araujo JLB, Gomes PAC, Nuernberg S, Neto MP, Oliveira GP, et al Notas sobre duas espécies de Lymnaea Lamark, 1799, hospedeiros intermediários da Fasciola hepatica no estado do Rio de Janeiro. (Mollusca, Gastropoda, Basommatophora, Lymnaeidae). Arq Univ Fed Rural. 1973;3:21-3.
49. Robinson MW, Dalton JP. Zoonotic helminth infections with particular emphasis on fasciolosis and other trematodiases. Philos Trans R Soc Biol Sci. 2009;364:2763-76.

50. Serra-Freire NM, Nuernberg S. Geopolitical dispersion of the occurrence of Fasciole hepatica in the state of Santa Catarina, Brazil. Mem Inst Oswaldo Cruz. 1992;87(Suppl 1):263-9.

51. Serra-Freire NM, Bordin EL, Lessa CSS, Scherer PO, Farias MT, Malacco A, et al. Reinvestigação sobre a distribuição da Fasciola hepatica no Brasil. Hora Vet. 1995;1(Edição extra):19-21.

52. Serra-Freire NM. Fasciolose hepática no Brasil: análise retrospectiva e prospectiva Cad Téc-Cient Esc Med Vet. 1999;1:9-70.

53. Thomas C, Jacquiet $\mathrm{P}$, Dorchies $\mathrm{P}$. La prévalence des helminthoses bovines a-t-elle été modifiée par la canicule de l'été 2003 dans le Sud-Ouest de la France? Parasite. 2007; $14: 265-8$.

54. Torgerson P, Claxton J. Epidemiology and control. In: Dalton JP, editor. Fasciolosis Wallingford: CABI Publishing; 1999. p. 113-49.

55. Ueno H, Gutierres VC, Mattos MJT, Muller G. Fascioliasis problems in ruminants in Rio Grande do Sul, Brazil. Vet Parasitol. 1982;11:185-91.

56. WHO. Working to overcome the global impact of neglected tropical diseases. Firs WHO report on neglected tropical diseases. Geneva: World Health Organization; 2010

Received: 20 December 2012

Accepted: 23 April 2013 